\title{
Accumulation of Some Heavy Metals on Flavoparmelia caperata and Usnea dasypoga as Bioindicators of Air Qualityy in Palembang City
}

\author{
Mirawati $^{1 *}$, Arinafril$^{2}$, M. Faizal ${ }^{3}$ \\ ${ }^{1}$ Environmental Management Department, Graduate School of Sriwijaya University, Jl. Padang Selasa No. 524 Bukit Besar Palembang Sumatera Selatan 30139, Indonesia \\ ${ }^{2}$ Department of Plant Pest and Disease, Faculty of Agriculture, Sriwijaya University, Jl. Palembang - Prabumulih KM.32 Kabupaten Ogan Ilir, Sumatera Selatan, Indonesia \\ ${ }^{3}$ Chemical Engineering Department, Faculty of Engineering, Sriwijaya University, Jl. Palembang - Prabumulih KM.32 Kabupaten Ogan Ilir, Sumatera Selatan, Indonesia \\ *Corresponding author: mira2meira@gmail.com
}

\begin{abstract}
Flavoparmelia caperata and Usnea dasypoga lichen for the first time was used to assess the concentration of heavy metals in the air in Palembang City. Five heavy metals $\mathrm{Cd}, \mathrm{Cu}, \mathrm{Pb}, \mathrm{Fe}$, and $\mathrm{Zn}$ were measured using the transplant method. Both samples of lichen were collected from Gununghalu, Bandung. The lichen was transplanted at 7 points on the roadside, after 8 weeks, samples were collected and analyzed using atomic adsorption spectrometry (AAS). The concentration of heavy metals accumulated in $F$. caperata was $\mathrm{Fe}>\mathrm{Cu}>\mathrm{Zn}>\mathrm{Pb}>\mathrm{Cd}$, on $\mathrm{U}$. dasypoga was $\mathrm{Fe}>\mathrm{Zn}>\mathrm{Cu}>\mathrm{Pb}>\mathrm{Cd}$. The results showed that both types of lichen were very suitable to be used as an air quality bioindicator. The EC ratio of both transplanted samples showed higher levels of accumulation in $U$. dasypoga with a significant accumulation rate on $\mathrm{Pb}$ metal followed by $\mathrm{Cu}, \mathrm{Cd}$, Zn, and Fe. Furthermore, dendrogram showed clustering based on the concentrations of heavy metals accumulated at each station due to differences in density and vehicle type. This indicated that the metals have the same source which derived from emissions of motor vehicles, road construction activities, and other local anthropogenic activities.
\end{abstract}

Keywords

Transplantation, lichen, accumulation, bioindicator, heavy metal

Received: 11 April 2018, Accepted: 7 June 2018

https://doi.org/10.26554/sti.2018.3.3.123-129

\section{INTRODUCTION}

The transportation sector is the main source of urban air pollution through gas emissions and particulate matter (Sujetoviene, 2013). Heavy metals are contained in ambient air especially air particulate PM2.5. Heavy metals released during road transport operations such as fuel combustion, catalytic converter, tire and brake pads wear, vehicle corrosion, road wear and road construction activities (Aslan et al., 2011; Yan et al., 2013; Dam-o, 2015). The presence of heavy metals in the air is considered as a useful indicator for assessing urban air quality.

Lichen had been used for many years to detect air quality in urban environments (Conti and Cecchetti, 2001) as a bioindicator for various types of air pollution such as metals (Logesh, 2014; Brown and Brown, 1991), sulfur dioxide pollution (Ahmed et al., 2016), and the effect of motor vehicle emissions on the distribution of lichen (Coffey and Fahrig, 2012; Sujetoviene, 2013). Lichen is able to absorb metal directly from the atmosphere far beyond their needs and collect it in the talus. The metal uptake depends on the heavy metal content in the air, the morphology of the lichen, and environmental parameters such as temperature, humidity and wind velocity (Garty, 2001).

Lichen is transplanted from unpolluted areas or far from polluted areas to the contaminated areas and then calculates pollution effects or accumulation of pollutants (Logesh, 2014). The transplantation method is used primarily in urban areas that lichen are rarely found. The transplanted lichen is sensitive to the pollutants especially the foliose and fruticose types. In this study, Palembang City was selected as a research area to analyze the accumulation of heavy metals in the atmosphere. Air pollution in Palembang City is strongly influenced by anthropogenic activities, high vehicle density and road construction activities make congestion almost in every road segment, making the road traffic as the main source of heavy metal pollution.

This study evaluates the effectiveness of the use of lichen as a biomonitor in identifying environmental risks from air pollution. This study used two different types of lichen with different talus shape, Flavoparmelia caperata and Usnea filipendula. Both types of lichen were transplanted at 7 locations with different characteristics. The accumulation of heavy metals in both lichen samples became the focus of research to assess the air quality in Palembang City. 


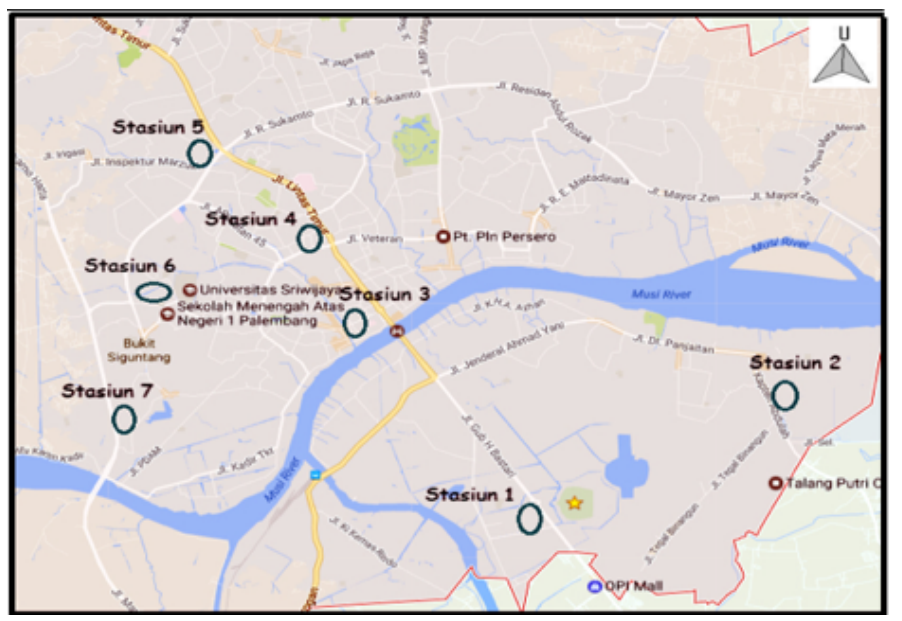

Figure 1. Map of transplant station

\section{EXPERIMENTAL SECTION}

\subsection{Transplant location}

The study was conducted in Palembang City; the transplant location was selected using survey method. The transplantation site consists of 7 stations characterized by different vehicle activities and diverse anthropogenic activities. Other classifications are based on anthropogenic activities such as road construction activities, commercial activities, industrial estates, and vehicle types which were passing through the road. The location of the transplant is shown in Figure 1.

The study was conducted for 5 months (June-October 2017 ) with a transplant period of 8 weeks, mid-June-August. The tools and materials which were used in this research are Plywood, nylon net, glue wax, knife, AAS, Oven, Eksikator, Furnace, pipette, measuring flask, cup, scales, Thermohygrometer, Anemometer, $\mathrm{HNO}_{3}, \mathrm{HCl}, \mathrm{Mg}\left(\mathrm{NO}_{3}\right)$, and $\mathrm{H}_{2} \mathrm{O}$ (distilled water).

\subsection{Lichen Transplantation}

Flavoparmelia caperata and Usnea dasypoga, previously known as Usnea filipendula are collected in June 2017 from areas far from air pollution, here in after referred to as control sites located in mountainous areas in the District of Gununghalu, Bandung Barat Regency (702'2.784 ” S, 107017’41.112”E, about 1134 $\mathrm{m}$ asl). The lichen selection criteria were based on the height of the tree, i.e. $2 \mathrm{~m}$ above the surface of the soil, $5-10 \mathrm{~cm}$ of lichen size, in healthy condition / in growth period, and both samples were taken from the tree and its substrate. $U$. dasypoga samples were taken from pine trees, while $F$. caperata were collected from fruit trees.

The lichen was transplanted in accordance to Yemets method (Yemets, 2013) at a distance of 0-5 $\mathrm{m}$ from the highway. Species of the lichen are placed on a wooden board $20 \times 30 \mathrm{~cm}$ and covered with nylon mesh. The wooden boards then were mounted on tree trunks at a height of $2 \mathrm{~m}$ vertically mimicking their natural location on tree trunks. Each station was mounted 3

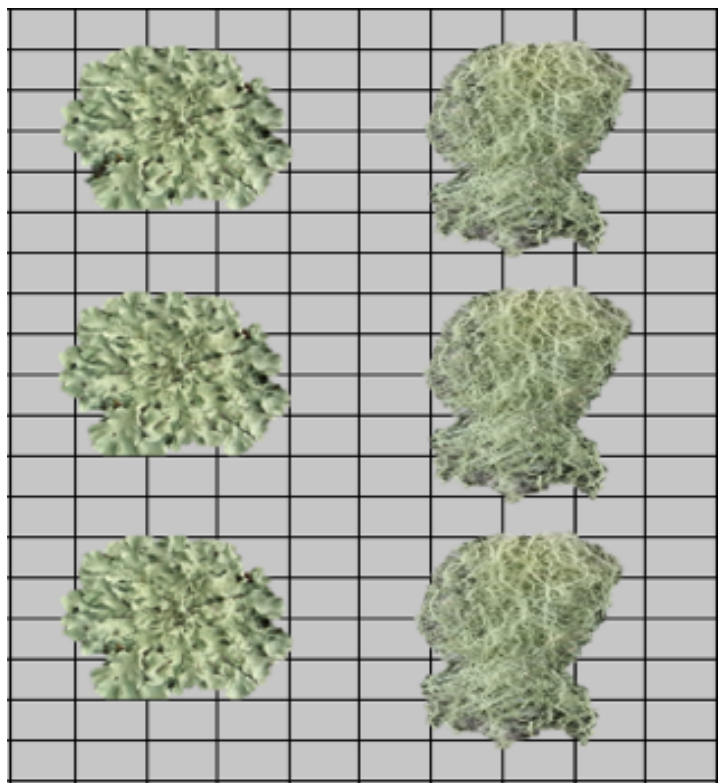

Figure 2. Transplant Position

lichen for each species, the position of the samples of lichen transplantation were shown in Figure 2. The transplants were positioned facing the road and exposed to direct sunlight.

\subsection{Analysis of heavy metals}

Lichen samples were collected from 7 stations then dried at oven on $105{ }^{\circ} \mathrm{C}$ temperature for 3 hours. The samples then were cooled in the indicator. These processes were carried out 3 times until a constant weight was obtained. Each sample then was burned in a furnace with a temperature of $500{ }^{\circ} \mathrm{C}$ until it turns into white ash. Then added $5 \mathrm{ml}$ of $\mathrm{HCl}$ and $\mathrm{HNO}_{3}$ solution in each sample until dissolved. After that each sample was added $10 \mathrm{ml}$ of distilled water. The solution then was fed into a measuring flask and subsequently the heavy metal content ( $\mathrm{Cd}, \mathrm{Cu}, \mathrm{Pb}, \mathrm{Fe}$, and $\mathrm{Zn})$ was measured using an Atomic Absorption Spectrometer (SNI 01-2896-1998). The heavy metal content of the samples calculated using the following formula:

$$
\text { heavymetalcontent }=\frac{C x V x f p}{m} x \% a d b k
$$

Where: $\mathrm{C}$ : The concentration of the calibration curve $(\mathrm{mg} / \mathrm{Kg})$ $\mathrm{V}$ : volume of dissolution (mL) Fp : dilution factor $\mathrm{M}$ : The dry weight of samples (g) \%adbk : Percentage on a dry weight basis

\subsection{Data analysis}

The accumulations of heavy metals in the exposed samples were assessed by comparing the concentration after exposure to control ratio (EC ratio) calculated according to Frati (Frati et al., 2005). To assess the accumulation or loss of heavy metals (A / L) in the lichen, a class 5 interpretation scale was used. To see the heavy metal content in the lichen was used multivariate 
Table 1. Characteristics of transplant sites

\begin{tabular}{|c|c|c|c|}
\hline No & Location & Koordinat & Characteristics \\
\hline \multirow[b]{2}{*}{1} & Jakabaring & $3^{\circ} 1 ’ 19.25^{\prime \prime} \mathrm{S}$ & \multirow[b]{2}{*}{ Low vehicle activity, road construction } \\
\hline & Jalan HA Bastari & $104^{\circ} 47^{\prime} 1.01^{\prime \prime} \mathrm{E}$ & \\
\hline \multirow{2}{*}{2} & Plaju & $3^{\circ} 0 ’ 28.50 ” \mathrm{~S}$ & \multirow{2}{*}{ Industry, low vehicle activity } \\
\hline & Jalan Kapten Abdullah & $104^{\circ} 49^{\prime} 8.84^{\prime \prime}$ ВТ & \\
\hline \multirow{2}{*}{3} & Fountain & $2^{\circ} 59^{\prime} 20.307^{\prime \prime S}$ & \multirow{2}{*}{ High vehicle activity, commercial area, road construction } \\
\hline & Jalan Merdeka & $104^{\circ} 45^{\prime} 36.85^{\prime \prime} \mathrm{E}$ & \\
\hline \multirow{2}{*}{4} & Charitas Intersection & $2^{\circ} 58^{\prime} 39.07 ” \mathrm{LS}$ & \multirow{2}{*}{ Office area, high vehicle activity, road construction, RS } \\
\hline & Jalan Kol A. Rivai & $104^{\circ} 45^{\prime} 5.54^{\prime \prime} \mathrm{BT}$ & \\
\hline \multirow{2}{*}{5} & Polda Intersection & $2^{\circ} 57^{\prime} 40.31 ” \mathrm{~S}$ & \multirow{2}{*}{ High vehicle activity, road construction } \\
\hline & Jalan Demang Lebar daun & $104^{\circ} 44^{\prime} 15.98^{\prime \prime} \mathrm{E}$ & \\
\hline \multirow{2}{*}{6} & Bukit & $2^{\circ} 59^{\prime} 8.500 ” \mathrm{~S}$ & \multirow{2}{*}{ Medium vehicle activity } \\
\hline & Jalan Ogan & $104^{\circ} 43^{\prime} 31.07^{\prime} \mathrm{E}$ & \\
\hline \multirow{3}{*}{7} & Musi 2 & $3^{\circ} 1$ '49.06” LS & \multirow{3}{*}{ High vehicle activity } \\
\hline & Jl. M. Yusuf Singedekane & $104^{\circ} 43^{\prime} 14.97^{\prime \prime}$ & \\
\hline & & $\mathrm{BT}$ & \\
\hline
\end{tabular}

analysis (Cluster Analysis) by grouping the location based on inter-group relationship. Data analysis was performed using PAST 3.16.

Table 2. Interpretation scale exposed-to-control ratio, EC ratio

\begin{tabular}{ll}
\hline EC ratio & Accumulation/loss \\
\hline $0-0.25$ & Severe loss \\
$0.26-0.75$ & Loss \\
$0.76-1.25$ & Normal \\
$1.26-1.75$ & Accumulation \\
$>1.75$ & Severe accumulation \\
\hline
\end{tabular}

\section{RESULTS AND DISGUSSION}

Samples of Flavoparmelia caperata and Usnea dasypoga was transplanted in Palembang City with different microclimate conditions with control area. Average Temperature, humidity and wind velocity were lower to the control area Table 3.

The concentration of heavy metals on $F$. caperata and $U$. dasypoga after 8 weeks of transplantation was shown in Table 4 with heavy metal concentrations in the lower control areas of the transplant samples. From the data obtained showed that both species could be used to detect air quality in urban areas. In F. caperata, Fe accumulation was ranked highest with the sequence of $\mathrm{Fe}>\mathrm{Cu}>\mathrm{Zn}>\mathrm{Pb}>\mathrm{Cd}$, the highest concentration at stations $1,3,5$. The order of metal concentrations in the $U$. dasypoga was $\mathrm{Fe}>\mathrm{Zn}>\mathrm{Cu}>\mathrm{Pb}>\mathrm{Cd}$. The highest concentrations were found at stations 3,6 , and 7 . Accumulated high enough to indicate higher levels of pollution load in the atmosphere.

Based on Table 4, the highest accumulation of heavy metals tended to be found at stations with high density. This suggests that vehicles are the main source of heavy metals in urban areas. Fe and $\mathrm{Zn}$ metals are an essential component of alloy pipe and wire on motor vehicles and released on the road due to mechanical abrasion and wear (Abechi et al., 2010). The fairly high of $\mathrm{Fe}$ uptake in F. caperata and $U$. dasypoga reflects the presence of larger Fe metals in the air. Construction activities contain heavy metals Fe because most road construction materials are iron (Dam-o, 2015) while $\mathrm{Zn}$ is emitted from car tires and worn brake pads (Aras et al., 2011).

$\mathrm{Pb}$ metal uptake in both lichen samples increased in comparison with controls even though the $\mathrm{Pb}$ metal content on fuel oil has been banned, $\mathrm{Pb}$ absorption indicated the availability of $\mathrm{Pb}$ in Palembang City air that is sourced from anthropogenic activity. In stations with high traffic densities $\mathrm{Pb}$ tended to increase, $(5.092 \mu \mathrm{g} / \mathrm{g})$ in F. caperata and (3.614 $\mu \mathrm{g} / \mathrm{g})$ on $U$. dasypoga. The relatively heavy traffic conditions by cars are the main cause of the high $\mathrm{Pb}$ (Kar et al., 2013). Cd was found in the lowest concentrations of all metals measured. $\mathrm{Cd}$ is a metal that is toxic to plants, in some previous studies, $\mathrm{Cd}$ associated with motor vehicles (Uluozlu et al., 2007) released by catalytic converter and flue gas (Aras et al., 2011). The concentration of $\mathrm{Cd}$ in this study was in accordance with a study conducted by Saiki et al. (Saiki et al., 2013) Cd metal concentrations in urban areas tend to be lower compared to the other metals.

$\mathrm{Cu}$ metal concentrations were not much different from control lichens, but at some stations showed a fairly high increase. The $\mathrm{Cu}$ source on the highway is derived from the corrosion of metal components on the car (Uluozlu et al., 2007), asphalt and brake wear are main source of $\mathrm{Cu}$ emissions (Winther and Slentø, 2010). Abah et al. (Abah, 2014) found significant increases in $\mathrm{Cu}$ concentrations at some road construction sites in Namibia City. Although this concentration is still below the threshold value but enough to prove that construction activity is a potential source.

The interesting thing here was the concentration of Fe metal 
Table 3. Temperature, humidity and wind speed at transplant location and area control

\begin{tabular}{lcccccccc}
\hline \multirow{2}{*}{ EnvironmentalFactors } & \multicolumn{7}{c}{ Location of Transplantations } \\
\cline { 2 - 8 } & Station 1 & Station 2 & Station 3 & Station 4 & Station 5 & Station 6 & Station 7 & \\
\hline Average Temperature $\left({ }^{\circ} \mathrm{C}\right)$ & 32.7 & 32.1 & 31.4 & 31.1 & 32.8 & 32.8 & 35.3 & 18 \\
Average Humidity $(\mathrm{mm})$ & 69.4 & 69.3 & 71.1 & 69.7 & 65.8 & 66.1 & 64.0 & 79 \\
Average Wind elocity $(\mathrm{m} / \mathrm{s})$ & 2.7 & 1.6 & 2.7 & 2.4 & 3.1 & 1.5 & 3.0 & 4 \\
\hline
\end{tabular}

Table 4. Accumulation of heavy metals $\mu \mathrm{g} / \mathrm{g}$ dry weight in moss samples of flavoparmelia caperata and Usnea filipendula

\begin{tabular}{|c|c|c|c|c|c|c|c|c|c|}
\hline \multirow[b]{2}{*}{ Lichen } & \multirow{2}{*}{\multicolumn{2}{|c|}{ Control }} & \multicolumn{7}{|c|}{ Station of Transsplantation } \\
\hline & & & Station 1 & Station 2 & Station 3 & Station 4 & Station 5 & Station 6 & Station 7 \\
\hline \multirow[t]{5}{*}{ Flavoparmelia caperata } & $\mathrm{Cd}$ & 0.035 & 0.110 & 0.037 & 0.106 & 0.056 & 0.075 & 0.061 & 0.057 \\
\hline & $\mathrm{Cu}$ & 3,314 & 3,952 & 5,573 & 11,442 & 5,809 & 6,064 & 3,556 & 3,429 \\
\hline & $\mathrm{Pb}$ & 1,965 & 3,965 & 3,317 & 5,092 & 2,645 & 3,441 & 2,239 & 4,159 \\
\hline & $\mathrm{Fe}$ & 27,067 & 45,605 & 37,612 & 34,938 & 44,147 & 47,489 & 23,912 & 39,912 \\
\hline & $\mathrm{Zn}$ & 3,605 & 8,480 & 6,687 & 6,570 & 7,464 & 9,163 & 4,428 & 7,061 \\
\hline \multirow[t]{5}{*}{ Usnea filipendula } & $\mathrm{Cd}$ & 0.027 & 0.027 & 0.062 & 0.064 & 0.069 & 0.052 & 0.072 & 0.072 \\
\hline & $\mathrm{Cu}$ & 1,083 & 1,668 & 3,158 & 7,922 & 1,217 & 6,921 & 4,089 & 3,667 \\
\hline & $\mathrm{Pb}$ & 0.26319444 & 1,417 & 1,333 & 2,357 & 1,675 & 2,597 & 2,620 & 3,614 \\
\hline & $\mathrm{Fe}$ & 26,958 & 28,740 & 48,817 & 42,777 & 44,550 & 47,578 & 47,031 & 57,323 \\
\hline & $\mathrm{Zn}$ & 3,766 & 4,702 & 7,209 & 6,888 & 7,387 & 8,424 & 8,133 & 11,002 \\
\hline
\end{tabular}

Descripion: The highest concentrations of each heavy metal in both samples at each station were written in bold

in F. caperata at station $6(23.912 \mu \mathrm{g} / \mathrm{g})$ and metal $\mathrm{Cd}$ on $U$. dasypoga at station $1(0.027 \mu \mathrm{g} / \mathrm{g})$. The accumulated levels are both at the same level even lower than the control area. This means that there was no increase in $\mathrm{Cd}$ in the transplanted lichen or an increase but lost rinse when rain falls. Rain can increase the absorption of elements by stimulating metabolism (Nash and Gries, 1995) also reducing it by removing particles from the surface of the talus (Brown and Brown, 1991). Lichen is a low-grade plant that has no cuticle as a cell protector, absorbed nutrients and contaminants will be converted to cell walls in crystalline form and when heavy rain will gradually be washed to maintain balance (Sett and Kundu, 2016).

The concentration of the elements obtained in the analysis of samples of $F$. caperata and $U$. dasypoga showed mixed results. To compare the accumulated rate of transplanted samples used the EC ratio scale (Frati et al., 2005). The value of EC Ratio in both samples is shown in Table 5 .

Based on EC values on both samples of lichen during 8 weeks of transplantations there were no cases of severe loss $(0<\mathrm{EC}<0.25)$ and loss $(0.25<\mathrm{EC}<0.75)$. The normal conditions $(0.75<\mathrm{EC}<1.25)$ were found in 11 cases, the accumulation conditions $(01.25<\mathrm{EC}<1.75)$ were found in 18 cases and severe accumulation conditions $(\mathrm{EC}>1.75)$ were found in 41 cases.

The rate of heavy metal accumulation in $U$. dasypoga was higher than F. caperata. The sequence of accumulation rates on F. caperata showed the greatest increase in Cd (2.05 times), concentration increase was also observed in 4 other heavy metals, $\mathrm{Cu}$ (1.72 times), $\mathrm{Pb}$ (1.81 times), $\mathrm{Zn}(1.98$ times), and $\mathrm{Fe}$ (1.44

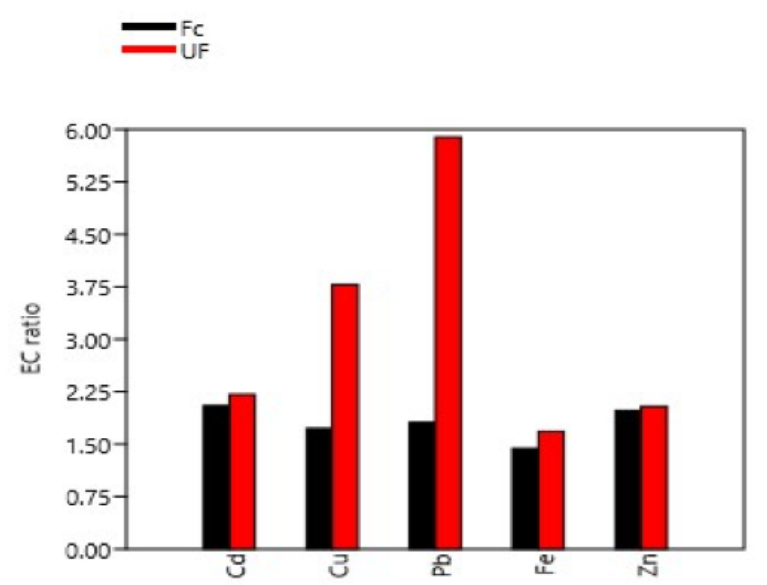

Figure 3. Comparison of the degree of heavy metal accumulation on Flavoparmelia caperata with Usnea dasypoga

times). While at $U$. dasypoga, biggest increase seen in metal $\mathrm{Pb}$ (5,89 times) followed by $\mathrm{Cu}$ (3,78 times), Cd (2,21 times), $\mathrm{Zn}$ (2.04 times) and Fe (1.68 times). Differences of accumulation level of heavy metals are influenced by the structure and shape of morphology of the lichen (Garty, 2001), environmental factors such as temperature and humidity (Coffey and Fahrig, 2012), and the availability of heavy metals in the environment. 
Table 5. The ratio of heavy metal accumulation to the exposed sample of the lichen was compared with the control sample at the transplantation sites

\begin{tabular}{ccccccccccc}
\hline & EC ratio & Class & EC ratio & Class & EC ratio & Class & Ec ratio & Class & EC ratio & Class \\
& Cd & $\mathrm{L} / \mathrm{A}$ & $\mathrm{Cu}$ & $\mathrm{L} / \mathrm{A}$ & $\mathrm{Pb}$ & $\mathrm{L} / \mathrm{A}$ & $\mathrm{Fe}$ & $\mathrm{L} / \mathrm{A}$ & Zn & $\mathrm{L} / \mathrm{A}$ \\
& 3.14 & $\mathrm{SA}$ & 1.19 & $\mathrm{~N}$ & 2.02 & $\mathrm{SA}$ & 1.68 & $\mathrm{~A}$ & 2.35 & $\mathrm{SA}$ \\
& 1.06 & $\mathrm{~N}$ & 1.68 & $\mathrm{~A}$ & 1.69 & $\mathrm{~A}$ & 1.39 & $\mathrm{~A}$ & 1.85 & $\mathrm{SA}$ \\
& $\mathbf{3 . 0 3}$ & $\mathrm{SA}$ & $\mathbf{3 . 4 5}$ & $\mathrm{SA}$ & $\mathbf{2 . 5 9}$ & $\mathrm{SA}$ & 1.29 & $\mathrm{~A}$ & 1.82 & $\mathrm{SA}$ \\
& 1.60 & $\mathrm{~A}$ & 1.75 & $\mathrm{~N}$ & 1.35 & $\mathrm{~A}$ & 1.63 & $\mathrm{~A}$ & 2.07 & $\mathrm{SA}$ \\
& 2.14 & $\mathrm{SA}$ & 1.83 & $\mathrm{SA}$ & 1.75 & $\mathrm{~A}$ & $\mathbf{1 . 7 5}$ & $\mathrm{A}$ & $\mathbf{2 . 5 4}$ & $\mathrm{SA}$ \\
& 1.74 & $\mathrm{~A}$ & 1.07 & $\mathrm{~N}$ & 1.14 & $\mathrm{~N}$ & 0.88 & $\mathrm{~N}$ & 1.23 & $\mathrm{~N}$ \\
& 1.63 & $\mathrm{~A}$ & 1.03 & $\mathrm{~N}$ & 2.12 & $\mathrm{SA}$ & 1.47 & $\mathrm{~A}$ & 1.96 & $\mathrm{SA}$ \\
\hline \multirow{5}{*}{ Usnea filipendula } & 1.00 & $\mathrm{~N}$ & 1.54 & $\mathrm{~A}$ & 3.74 & $\mathrm{SA}$ & 1.07 & $\mathrm{~N}$ & 1.25 & $\mathrm{~N}$ \\
& 2.30 & $\mathrm{SA}$ & 2.92 & $\mathrm{SA}$ & 3.52 & $\mathrm{SA}$ & 1.81 & $\mathrm{~A}$ & 1.91 & $\mathrm{SA}$ \\
& 2.37 & $\mathrm{SA}$ & 7.31 & $\mathrm{SA}$ & 6.22 & $\mathrm{SA}$ & 1.59 & $\mathrm{~A}$ & 1.83 & $\mathrm{SA}$ \\
& 2.56 & $\mathrm{SA}$ & 1.12 & $\mathrm{~N}$ & 4.42 & $\mathrm{SA}$ & 1.65 & $\mathrm{~A}$ & 1.96 & $\mathrm{SA}$ \\
& 1.93 & $\mathrm{SA}$ & 6.39 & $\mathrm{SA}$ & 6.85 & $\mathrm{SA}$ & 1.76 & $\mathrm{SA}$ & 2.24 & $\mathrm{SA}$ \\
& $\mathbf{2 . 6 7}$ & $\mathrm{SA}$ & 3.78 & $\mathrm{SA}$ & 6.91 & $\mathrm{SA}$ & 1.74 & $\mathrm{~A}$ & 2.16 & $\mathrm{SA}$ \\
& 2.67 & $\mathrm{SA}$ & 3.40 & $\mathrm{SA}$ & $\mathbf{9 . 5 4}$ & $\mathrm{SA}$ & $\mathbf{2 . 1 3}$ & $\mathrm{SA}$ & $\mathbf{2 . 9 2}$ & $\mathrm{SA}$ \\
\hline
\end{tabular}

Description: $\mathrm{N}=$ normal, $\mathrm{A}=$ accumulation, $\mathrm{SA}=$ Severe accumulation. The highest level on each station is indicated by the number in bold.

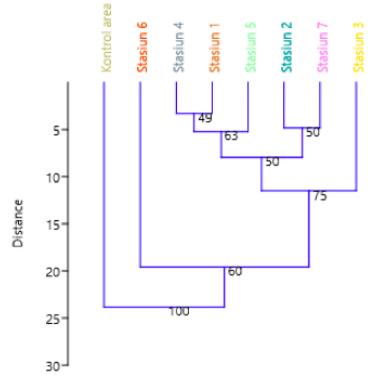

Falavoparmelia caperata

Figure 4. Cluster analysis of 7 transplantation stations in Kota Palembang city and area control based on Flavoparmelia caperata and Usnea filipendula metal content after 8 weeks of transplantation with cophenetic correlation index 0.9407 and 0.8803 .

Furthermore, heavy metal accumulation in both samples was analyzed by Cluster analysis (CA) using distance measures as a measure of inequality and paired group (UPGMA) as a clustering algorithm (Mitrovic et al., 2012). Size of inequality is used to see the difference of heavy metal accumulation at each transplant station.

From the picture above shows on $F$. caperata dendrogram formed 4 groups: (1) Area control; (2) station 6; (3) stations 2, $1,5,2$, and 7 ; (4) station 3 whereas in $U$. filipendula formed 3 groups: (1) control area and station 1; (2) stations 2, 3, 4, 5, and 6 ; (3) Station 7. Based on dendrogram results in both samples, area controls tended to be separated from other groups. It was as expected that the area selected as the control area was far from air pollution and shows the least impact exposure to heavy metals compared to urban areas.

The main factor that distinguishes the grouping of each station in this study was the degree of heavy metal accumulation at each station with different densities and vehicle types. This indicated that the highway is the main source of heavy metals accumulation. Research conducted by Huang et al. (Huang et al., 2017) in Singapore found the pattern of heavy metal concentrations in different locations highly dependent on vehicle density and distance from the highway. The same is shown by Aslan et al. (Aslan et al., 2011) that the strong correlations of heavy metal groups such as $\mathrm{Fe}, \mathrm{Mn}, \mathrm{Zn}, \mathrm{Cu}, \mathrm{Cd}, \mathrm{Se}, \mathrm{Cr}, \mathrm{Pb}$ and $\mathrm{Ni}$ as pollutants are sourced from motor vehicle emissions.

The results of this study indicated that the concentration of heavy metals in the moss lichen samples at each station was different and highly dependent on the density of the traffic. At stations with high vehicle densities heavy metal accumulation tended to be higher. The relationship between metal content and traffic volume showed that metallic elements, emitted as pollutants derived from vehicles and also industrial emissions that spread (Kar et al., 2013). Furthermore, a recent study conducted by Liu et al. (Liu et al., 2017) and Petrova et al. (Petrova, 2015) found that anthropogenic and urban traffic activities were a very important factor in increasing the accumulation of metals such as $\mathrm{Cd}, \mathrm{Zn}, \mathrm{Pb}, \mathrm{Fe}$ and $\mathrm{Cr}$. The further the distance from the highway accumulation of heavy metals is getting lower. 


\section{CONGLUSIONS}

The results showed the success of lichen transplantation as an air quality biomonitor in Palembang City. This research used 2 types of lichen, foliose and fruticose which have different sensitivity. Variations in accumulated heavy metal concentrations illustrated that both species of Flavoparmelia caperata and Usnea filipendula are good accumulators of heavy metals Cd, $\mathrm{Cu}, \mathrm{Pb}, \mathrm{Fe}$, and $\mathrm{Zn}$ and were particularly suitable for air quality biomonitors.

After 8 weeks of transplantation both samples showed an increase in metal, reflected the presence of heavy metals in the air. The order of heavy metals accumulated in Flavoparmelia caperata: $\mathrm{Fe}>\mathrm{Cu}>\mathrm{Zn}>\mathrm{Pb}>\mathrm{Cd}$ and on Usnea filipendula: $\mathrm{Fe}>\mathrm{Zn}>\mathrm{Cu}>\mathrm{Pb}>\mathrm{Cd}$. Flavoparmelia caperata exhibits a greater accumulation of capacity of heavy metals, but when compared with Exposed to Control (EC) the rate of accumulation of Usnea filipendula is higher than that on Flavoparmelia caperata. Metal sources in Palembang City come from motor vehicle emissions, road construction activities, and other local anthropogenic activities / transplantation site characteristics. The highest concentrations of heavy metals were found in stations with high traffic density. The dendrogram results showed the proximity of $\mathrm{Fe}$ and $\mathrm{Zn}, \mathrm{Pb}$ and $\mathrm{Cd}$ metals which indicate the metal was from the same source. Likewise, transplant stations with low density tended to form the same group.

\section{REFERENCES}

Abah, J. (2014). Survey of the Levels of some Heavy Metals in Roadside Dusts along Katima Mulilo Urban Road Construction, Namibia. American Journal of Environmental Protection, 3(1); 19

Abechi, E., O. J. Okulanola, S. M. J. Zubairu, A. Usman, and E. Apene (2010). Evaluation of heavy metals in roadside soils of major streets in Jos metropolis, Nigeria. Journal of Environmental Chemistryand Ecotoxicology., 2(6); 98-102

Ahmed, M., Z. Boumedris, A. Tahar, and M. Djebar (2016). Impact of an Atmosphere Rich in Sulfur Diokxide on Foliase Lichen Species Flavoparmelia Caperata (L) Hale from the El Kala National Park (Northeast Algerian). , . International Journal of Scientific Research in Science and Technology, 2(1); 21-27

Aras, S., T. Beyaztaş, D. Cansaran-Duman, and E. GökçeGündüzer (2011). Evaluation of genotoxicity of Pseudevernia furfuracea (L.) Zopf by RAPD analysis. Genetics and Molecular Research, 10(4); 3760-3770

Aslan, A., A. Çiçek, K. Yazici, Y. Karagöz, M. Turan, F. Akkuş, and S. Yildirim (2011). The assessment of lichens as bioindicator of heavy metal pollution from motor vehicles activites. African Journal of Agricultural Research, 6(7); 1698-1706.

Brown, D. H. and R. M. Brown (1991). Mineral Cycling and Lichens: The Physiological Basis. The Lichenologist, 23(03); 293-307

Coffey, H. M. P. and L. Fahrig (2012). Relative effects of ve- hicle pollution, moisture and colonization sources on urban lichens. Journal of Applied Ecology, 49(6); 1467-1474

Conti, M. and G. Cecchetti (2001). Biological monitoring: lichens as bioindicators of air pollution assessment - a review. Environmental Pollution, 114(3); 471-492

Dam-o, P. (2015). Examination of Some Heavy Metal Pollution in Roadside Plants Using X-Ray Spectroscopy. Ph.D. thesis, University of Łódź.

Frati, L., G. Brunialti, and S. Loppi (2005). Problems Related to Lichen Transplants to Monitor Trace Element Deposition in Repeated Surveys: A Case Study from Central Italy. Journal of Atmospheric Chemistry, 52(3); 221-230

Garty, J. (2001). Biomonitoring Atmospheric Heavy Metals with Lichens: Theory and Application. Critical Reviews in Plant Sciences, 20(4); 309-371

Huang, X., L. Wang, A. K. C. Laserna, and S. F. Y. Li (2017). Correlations in the elemental and metabolic profiles of the lichen Dirinaria picta after road traffic exposure. Metallomics, 9(11); 1610-1621

Kar, S., A. C. Samal, J. P. Maity, and S. C. Santra (2013). Diversity of epiphytic lichens and their role in sequestration of atmospheric metals. International Journal of Environmental Science and Technology, 11(4); 899-908

Liu, H.-J., J.-G. Wang, Y. Xia, M.-J. Yang, S.-W. Liu, L.C. Zhao, X.-P. Guo, Y.-J. Jiang, X. Li, Q.-F. Wu, and S.B. Fang (2017). Elemental compositions of lichens from Duolun County, Inner Mongolia, China: Origin, road effect and species difference. Scientific Reports, 7(1)

Logesh, A. (2014). Lichen as indicator of metal pollution in the vicinity of SIPCOT industries in Cuddalore, southeast coast of India. Mycosphere, 5(5); 681-687

Mitrovic, T., S. Stamenković, V. Cvetković, T. Đekić, R. Baošić, J. Mutić, T. Anđelković, and A. Bojić (2012). Bioindication of Heavy Metal Pollution in the Area of Southeastern Serbia by Using Epiphytic Lichen Flavoparmelia caperata (L.) Hale. Journal of Biological Science, 3(2); 53-60

Nash, T. H. and C. Gries (1995). The response of lichens to atmospheric deposition with an emphasis on the Arctic. Science of The Total Environment, 160-161; 737-747

Petrova, S. (2015). LICHEN-BAGS AS A BIOMONITORING TECHNIQUE IN AN URBAN AREA. Applied Ecology and Environmental Research, 13(4); 915-923

Saiki, M., E. Alves, F. Genezini, and P. Saldiva (2013). Comparative Study of the Suitability of Two Lichen Species for Trace Element Atmospheric Monitoring. International $\mathrm{Nu}$ clear Atlantic Conference - INAC 2013, 46(5)

Sett, R. and M. Kundu (2016). Epiphytic Lichens: Their Usefulness as Bio-indicators of Air Pollution of Air Pollution. Donnish Journal of Research in Environmental Studies, 3(3); 1724

Sujetovienè, G. (2013). Biomonitoring of urban air quality in Kaunas City (Lithuania) using transplanted lichens. Biologija, 59(2)

Uluozlu, O., K. Kinalioglu, M. Tuzen, and M. Soylak (2007). Trace Metal Levels in Lichen Samples from Roadsides in 
East Black Sea Region, Turkey. Biomedical and Environmental Sciences, 20; 203-207

Winther, M. and E. Slentø (2010). Heary Metal Emissions for Danish Road Transport; NERI Technical Report No. 780. Aarhus Universitet, Roskilde, Denmark

Yan, X., D. Gao, F. Zhang, C. Zeng, W. Xiang, and M. Zhang (2013). Relationships between Heavy Metal Concentrations in Roadside Topsoil and Distance to Road Edge Based on Field Observations in the Qinghai-Tibet Plateau, China. International Journal of Environmental Research and Public Health, 10(3); 762-775

Yemets, O. A. (2013). Assessments of traffic pollutants along a rural highway roadside in southern Norway by quantifying lichen responses 